\title{
A comparative analysis of Alexandrium catenella/tamarense blooms in Annaba Bay (Algeria) and Thau lagoon (France); phosphorus limitation as a trigger
}

\section{Analyse comparative des efflorescences d'Alexandrium catenella/tamarense en baie d'Annaba (Algérie) et dans l'étang de Thau (France) : limitation en phosphore comme élément déclencheur}

\author{
Imene Hadjadji, ${ }^{\mathrm{a}, \mathrm{b}}$, Hocine Frehi ${ }^{\mathrm{b}}$, Lembarek Ayada ${ }^{\mathrm{b}}$, Eric Abadie $^{\mathrm{c}}$, Yves Collos $^{\mathrm{a}, *}$
}

\author{
a UMR 5119, UM2-CNRS-IRD, Écologie des systèmes marins côtiers, université Montpellier 2, 34095 Montpellier \\ cedex 5, France \\ b Laboratoire " bioressources marines », université Badji-Mokhtar-Annaba, BP 12, El-Hadjar, 23000 Annaba, \\ Algeria

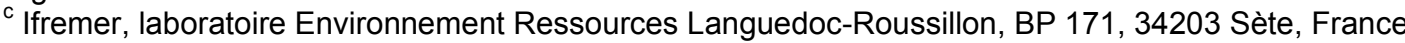 \\ *: Corresponding author : Yves Collos, email address : yves.collos@univ-montp2.fr
}

\begin{abstract}
:
Environmental conditions ultimately leading to blooms of the toxic dinoflagellate Alexandrium catenella/tamarense were investigated at two Mediterranean sites (Annaba Bay, Algeria and Thau lagoon, France). Three years were examined in details: 1992 (a pre-Alexandrium period), 2002 (a year with the first bloom in Annaba) and 2010 (a year with a major bloom in Annaba). Most conditions were similar, but ammonium concentrations were much higher in Annaba (up to $100 \mu \mathrm{M}$ ) than in Thau (up to $10 \mu \mathrm{M}$ ). First records of $A$. catenella/tamarense were in 1995 for Thau and 2002 for Annaba, and coincided with soluble reactive phosphorus (SRP) decreasing below a concentration of about $1 \mu \mathrm{M}$. No other environmental variable could be related to those blooms. Thus, it is likely that the large reductions in SRP at both sites led to phosphorus limitation of a certain number of phytoplankton species and favored the development of $A$. catenella/tamarense.
\end{abstract}

\section{Résumé}

Les conditions du milieu amenant à des efflorescences du dinoflagellé toxique Alexandrium catenella/tamarense ont été suivies sur deux sites méditerranéens (la baie d'Annaba, Algérie et l'étang de Thau, France). Trois années ont été examinées en détail : 1992 (période pre-Alexandrium), 2002 (première efflorescence à Annaba) et 2010 (efflorescence majeure à Annaba). La plupart des conditions étaient comparables, sauf pour l'ammonium, avec des concentrations bien plus fortes à Annaba (jusqu'à $100 \mu \mathrm{M}$ ) qu'à Thau (jusqu'à $10 \mu \mathrm{M}$ ). Les premières observations d'A. catenella/tamarense ont été réalisées en 1995 à Thau et 2002 à Annaba, et ont coïncidé avec le passage des concentrations en phosphore réactif dissous (PRD) sous la barre des $1 \mu \mathrm{M}$. Aucune autre variable du milieu n'a pu être reliée à l'apparition de ces efflorescences. II est donc probable que 
les fortes diminutions en PRD aux deux sites aient entraîné une limitation par le phosphore d'un certain nombre d'espèces phytoplanctoniques et favorisé le développement d'A. catenella/tamarense.

\author{
Keywords : Alexandrium catenella/tamarense ; Blooms ; Algeria ; France ; Mediterranean \\ Mots clés : Alexandrium catenella/tamarense ; Efflorescences ; Algérie ; France ; Méditerranée
}

\title{
1. Introduction
}

The genus Alexandrium belongs to one of the most important genera of harmful algal blooms (HABs) producing Paralytic Shellfish Poisoning (PSP) toxins [1]. Alexandrium species have a worldwide distribution, being present in coastal zones, continental shelf waters, in temperate as well as tropical areas [2]. The species $A$. catenella, $A$. tamarense and $A$. fundyense are the most toxic of the genus Alexandrium. Together, these species make up the A. tamarense complex [1] and [3]. Such species are often observed around the Mediterranean region [2]. In the northern part, $A$. catenella has first been reported in the Balearic islands in 1983 [4], and later on the French [5], Spanish [6] and Italian [7] coasts. In the southern part, Alexandrium species have been reported in Morocco [8], [9], [10] and [11], Tunisia [12] and [13], and Algeria [14].

A. catenella blooms in inorganic nutrient rich [6] and [15] and nutrient poor [16] and [17] waters. This is from the viewpoint of inorganic nutrients. The $A$. tamarense complex has been classified as a « frontal zone taxon » or " mixing-drift » group [18]. and therefore characteristic of areas that are unstable and intermediate between high and low inorganic nutrients. Very little is known generally about dissolved organic nutrients at those sites. It is therefore difficult to find recurrent patterns of bloom development for this mixotrophic species in relation with trophic conditions. Comparative studies of HABs ecosystems have been recognized as a way to deal with such difficulties and could "reveal fundamental processes governing population development" [19]. 
In this study, we compare A.catenella/tamarense dynamics in two contrasted sites in the Mediterranean. The first one is the relatively eutrophic [14] Bay of Annaba (Algeria) and the second is the Thau lagoon (France) that has recently gone through a period of

oligotrophication [20]. We try to relate those blooms to environmental factors in those two coastal sites on both sides of the Mediterranean Sea, and deduce possible causes of their recent development and recurring presence. We study 3 different years over an 18 year period, one being "pre-Alexandrium", one coinciding with the first A. catenella bloom in Annaba and the last one with a very large A. catenella bloom in Annaba. As the Thau lagoon blooms were connected with oligotrophication, we selected a period over which the same phenomenon appeared to take place in Annaba.

\section{Material and methods}

\subsection{Study sites}

The Bay of Annaba is located in the eastern part of Algeria (Fig. 1), between cape Rosa $\left(36^{\circ} 38^{\prime} \mathrm{N}, 8^{\circ} 15^{\prime} \mathrm{E}\right)$ and Cape de Garde $\left(36^{\circ} 38 \mathrm{~N}, 7^{\circ} 16^{\prime} \mathrm{E}\right)$, with a maximal depth of 50 m. The main temporary rivers (oueds) are Oued Seybouse (second river in Algeria), Oued Boudjemâa carrying urban and industrial effluents, and Oued Kouba carrying sewage waters. Alexandrium catenella has bloomed periodically since 2002 in this bay [14].

The Thau lagoon is a shallow marine lagoon located on the French Mediterranean coast $\left(43^{\circ} 24^{\prime} \mathrm{N}, 3^{\circ} 36^{\prime} \mathrm{E}\right)$ covering $75 \mathrm{~km}^{2}$ (Fig. 2). The mean depth is about $4 \mathrm{~m}$, with a maximum of $10 \mathrm{~m}$. The lagoon is connected to the sea by 3 narrow channels. Three oyster farming areas are located along the northwestern shore. The lagoon represents $10 \%$ of French annual oyster production and is the main oyster production center on the Mediterranean. Since 
100 1998, it has experienced recurrent blooms of Alexandrium catenella that periodically threaten

101 economic activities [20].

102 2.2. Sampling

103 Sampling stations for Annaba Bay

104 Station $1\left(36^{\circ} 54.073^{\prime} \mathrm{N}, 7^{\circ} 46.929^{\prime} \mathrm{E}\right)$ has a depth of $5 \mathrm{~m}$ and is sheltered from dominant (NW)

105 winds, with a rocky/sandy bottom.

106 Station $2\left(36^{\circ} 53.976^{\prime} \mathrm{N}, 7^{\circ} 47.111^{\prime} \mathrm{E}\right)$ is deeper $(13 \mathrm{~m})$ than station 1 and is located in front of

107 the commercial harbor. It is subject to major land influence through input from Oued

108 Seybouse and Oued Boudjemaa and is considered eutrophic relative to station 1. Bottom

109 sediments are silty. The sampling frequency was twice a month.

110 Sampling stations for Thau lagoon

111 Station B $\left(43^{\circ} 26.070^{\prime} \mathrm{N}, 3^{\circ} 39.920^{\prime} \mathrm{E}\right)$ is located at one of the deepest part of the lagoon $(8 \mathrm{~m})$

112 Station A5 $\left(43^{\circ} 26.916^{\prime} \mathrm{N}, 3^{\circ} 40.300^{\prime} \mathrm{E}\right)$ is located in the Angle Creek and is shallower (2 m)

113 and more sheltered than Station B. The sampling frequency varied from 1 to 8 samples per

114 month for physical variables. For chemical and biological variables, sampling was carried out

115 at least twice a month at station B.

116 2.3. Physical variables

117 In Annaba, surface temperature and salinity were measured with a WTW 191 multiparameter

118 probe (precision $0.1^{\circ} \mathrm{C}$ for temperature and 0.05 for salinity).

119 For Thau, the Ifremer observation network provided records of surface water temperature and

120 salinity (monthly means).

121 2.4. Nutrients

122 At both sites, samples for ammonium determination were immediately fixed and measured at

123 the laboratory [21]. Samples for the other nutrients were kept in the cold and dark, then frozen

124 at $-20^{\circ} \mathrm{C}$ until analysis. Nitrate [22], nitrite [23] and soluble reactive phosphorus (SRP)[24] 
125 were measured after thawing at room temperature. Detection limits were $0.05,0.01,0.05$ and

$1260.02 \mu \mathrm{M}$ for nitrate, nitrite, ammonium and SRP respectively.

127 2.5. Biological variables

128 Chlorophyll

129 In Annaba, chlorophyll a was measured by spectrophotometry [25]. In Thau lagoon,

130 chlorophyll a was estimated from $90 \%$ acetone extracts and fluorimetry [26] or

131 spectrofluorometry [27].

132 Microphytoplankton.

133 In Annaba, for the qualitative survey of phytoplankton, horizontal net tows were carried out at

$13450 \mathrm{~cm}$ below the surface, with a $20 \mu \mathrm{m}$ mesh size net. During Alexandrium blooms and for the

135 quantitative study, bucket sampling was used, and 40 liters were filtered on a $20 \mu \mathrm{m}$ mesh

136 size net. Samples were then resuspended in a $100 \mathrm{ml}$ volume, then subsamples of 1 or $5 \mathrm{ml}$

137 were used depending on the cell density. Samples were immediately fixed with buffered

138 formaldehyde (5\% final concentration). Identification was by electron microscopy in 2002

139 [14] and by optical microscopy in 2010, using morphological criteria. Both 2 cell and 4 cell

140 chains were observed.

141 In Thau lagoon, at least one liter of sea water was taken with a sampling bottle. Additions of

$1420.2 \mathrm{ml}$ to $0.4 \mathrm{ml}$ Lugol's solution per $100 \mathrm{ml}$ was carried out for quantitative analysis. A

143 counting chamber was filled with $10 \mathrm{ml}$ of fixed sample for sedimentation [28].

144 Phytoplankton cells greater than $10 \mu \mathrm{m}$ equivalent cell diameter were counted by optical

145 microscopy.

146 2.6. Statistical analyses

147 Variables were compared by Kruskal-Wallis one-way analysis of variance by ranks and

148 Dunn's multiple comparison tests.

149 
152 In 1992, A. catenella/tamarense had not yet been recorded either in Thau lagoon [5] or in

153 Algeria [14].

\section{3.1. Alexandrium catenella/tamarense blooms}

155 Alexandrium catenella was first observed in Annaba in March 2002 and in Thau in July 1995.

156 Temporal changes of cell densities during 2002 are shown for station 2 in Annaba and

157 stations A5 and B at Thau (Fig. 3). Highest monthly mean cell densities (117000 cells L $\left.{ }^{-1}\right)$ in

158 Annaba were recorded in March with a secondary peak in December (200 cells $\left.\mathrm{L}^{-1}\right)$. In Thau,

159 monthly mean cell densities were generally higher at $\mathrm{A} 5$ (maximum of 66700 cells $\mathrm{L}^{-1}$ in

160 May) than at station B (maximum of 5400 cells $\mathrm{L}^{-1}$ also in May), with a secondary peak in

161 August (9600 cells L $\left.{ }^{-1}\right)$.

162 In 2010, 2 stations were sampled in Annaba (Fig. 4) with higher cell densities at Station 2 (up

163 to 681000 cells $\mathrm{L}^{-1}$ in May). At station 1, monthly mean cell densities never exceeded 73000

164 cells $\mathrm{L}^{-1}$ (also in May). For individual dates, a record peak of $1.38 \times 10^{6}$ cells $\mathrm{L}^{-1}$ was recorded

165 in May 2010 at the surface of station 2. This was the highest cell density ever recorded so far

166 in Annaba.

167 In Thau, during the same year, no bloom developed in the spring, but cell densities reached a

168 maximum of 4400 cells $\mathrm{L}^{-1}$ in September at station A5 and 1500 cells $\mathrm{L}^{-1}$ also in September at 169 station B.

170 In 2002, there appeared to be no synchrony in blooms between sites (Fig. 3), but in 2010,

171 there was a bimodal distribution at both sites, with maxima in May-June and September-

172 October (Fig. 4).

173

174 3.2. Environmental factors 
175 Table 1 summarizes the ranges of physical and chemical variables at both sites. Sea surface temperatures were higher in Annaba than in Thau. The range of salinities was larger in Thau than in Annaba, with maximal values being greater in Thau lagoon. Maximal nitrate, ammonium and SRP concentrations were observed in Annaba, and were sometimes greater than in Thau by an order of magnitude, such as for ammonium. Concerning phytoplankton

180 biomass, the range of chl a values was about the same.

181 Table 2 summarizes the changes in environmental parameters occurring over an 18 year 182 period. The year 1992 can be considered as a "pre-Alexandrium" period for both sites. No

183 significant changes in either annual mean SST, salinity (not shown) or ammonium occurred 184 over this period at either site. In Annaba, the most spectacular changes were due to nitrate 185 concentrations that decreased by a factor of 50 (significant difference with $\mathrm{p}<0.001$ ) and specifically SRP concentrations that decreased by a factor of 250 (significant difference with $\mathrm{p}<0.001$ ), from a mean annual value of $17.4 \mu \mathrm{M}$ in 1992 to $0.07 \mu \mathrm{M}$ in 2010 . In Thau, the most dramatic decrease in SRP occurred between 1972 and 1992 (from about 10 to $1 \mu \mathrm{M}$ in summer and from $3 \mu \mathrm{M}$ to undetectable levels in winter). Between 1992 and 2010, the 190 decrease was significant $(\mathrm{p}<0.05)$.

4. Discussion

194 Although nitrate decreased dramatically between 1992 and 2010 in Annaba, nitrogen

195 limitation is unlikely because ammonium levels remained high (Table 2). The decrease in

196 SRP was due to the discontinuation of phosphogypsum outputs from a local fertilizer plant in 197 Annaba (M. Retima, pers. com.), and from implementation of sewage treatment plants in 198 Thau [29]. Concerning A. catenella ability to use low SRP levels, laboratory studies show that 199 the half -saturation constant for SRP uptake was variable in cultures, depending on the growth 
rate, but could reach values as low as $0.03 \mu \mathrm{M}$ for strain ACT03 and $0.01 \mu \mathrm{M}$ for strain TL01

201 [30]. This indicates that A. catenella could be a very strong competitor at the low SRP concentrations recently observed in Annaba Bay. An alternative to its periodic dominance is dissolved organic phosphorus use. Alkaline phosphatase activity was induced in A. catenella at SRP levels between 0.4 and $1 \mu \mathrm{M}$ [30] that are intermediate values between those observed in 2002 and 2010 in Annaba Bay.

Thus it seems very likely that the appearance of blooms of A. catenella in Annaba Bay is due to SRP reaching very low levels where other members of the phytoplankton community cannot compete for the acquisition of this limiting resource.

This situation is similar to that experienced in Thau lagoon [20] where SRP reached

210 undetectable winter levels in 1992-1993 and A. catenella was first reported in 1995.

211 A parallel can also be made with the Seto Inland Sea (Japan) where SRP decreased from 0.7 to $0.2 \mu \mathrm{M}$ between 1978 and 1984 [31]. A. catenella vegetative cells were first reported in this area in 1982 [32], so that $A$. catenella probably started to bloom when SRP reached levels between 0.7 and $0.2 \mu \mathrm{M}$. In the Gulf of Olbia (Sardinia, Italy), the first A. catenella bloom was reported in 1999 [33] under conditions of SRP below $1 \mu \mathrm{M}$ that were lower than

216 observed in 1992-1993, a situation also similar to the results presented here.

\section{Conclusions}

This inter-site comparison between the Northern and Southern coasts of the Mediterranean

221 has revealed that one of the causes of the development of A. catenella/tamarense is the onset of inorganic phosphorus limitation in both environments that allowed this organism to develop periodically and produce recurrent blooms. No other environmental variable could be related to the emergence of this organism. Such an explanation is an alternative to the general 
concept that eutrophication leads to harmful algal blooms and may require a revision of

226 coastal water management policies.

6. Acknowledgements

229 We wish to thank the anonymous referee and Ian Jenkinson for useful comments.

References

[1] D.M. Anderson, T. J. Alpermann, A.D. Cembella, Y. Collos, E. Masseret, M. Montresor, The globally distributed genus Alexandrium: Multifaceted roles in marine ecosystems and impacts on human health, Harm. Algae 14 (2012) 10-35.

[2] E.L. Lilly, K.M. Halanych, D.M. Anderson, Species boundaries and global biogeography of the Alexandrium tamarense complex (Dinophyceae), J. Phycology 43 (2007) 13291338.

[3] E. Balech, The genus Alexandrium or Gonyaulax of the tamarensis group, in: D.M. Anderson, A.W. White, D.G. Baden (Eds.), Toxic Dinoflagellates, Elsevier, Amsterdam,

[4] R. Margalef, M. Estrada, Synoptic distribution of summer microplankton (Algae and protozoa) across the principal front in the Western Mediterranean, Invest. Pesqueria 51 (1987) 121-140.

[5] E. Abadie, Z. Amzil, C. Belin, M.A Comps, P. Elziere. Papayanni, P. Lassus, C. Le Bec, C. Marcaillou. Le Baut, E. Nezan, R. Poggi, Contamination de l'étang de Thau par Alexandrium tamarense: Episode de novembre à décembre 1998. Ifremer, Plouzané, France, 1999 p. 44. 
[6] M. Vila, E. Garcés, M. Maso, J. Camp, Is the distribution of the toxic dinoflagellate Alexandrium catenella expanding along the NW Mediterranean coast? Mar. Ecol. Prog. Ser. 222 (2001) 73-83.

252 [7] A. Luglie, M.G. Giaccobe, A. Sannio, F. Fiocca, N. Sechi, First record of the dinoflagellate Alexandrium catenella (Whedon et Kofoid) Balech (Dinophyta), a potential producer of Paralytic Shellfish Poisoning, in Italian waters (Sardinia, Tyrrhenian Sea), Bocconea 16 (2) (2003) 1045-1051.

[8] L. Tahri-Joutei, M. Maghraoui, R. Bouta1b, Toxic phytoplankton and phycotoxins in the Mediterranean coast of Morocco from 1994 to 2000, in: A. Villalba, B. Reguera, J.L. Romalde, R. Beiras (Eds.), Molluscan Shellfish Safety, Xunta de Galicia and COI of UNESCO, Santiago de Compostela, 2003, pp. 187-195.

[9] A. Bennouna, O. Assobhei, B. Berland, J. El Attar, Étude des populations phytoplanctoniques de la lagune de Oualidia (Maroc); dinoflagellés potentiellement nuisibles, Mar. Life 10 (2000) 3-18.

[10] A. Bennouna, B. Berland, J. El Attar, O. Assobhei, Eau colorée à Lingulodinium polyedrum (Stein) Dodge, dans une zone aquacole du littoral du Doukkala (Atlantique marocain), Oceanol. Acta 25 (2002) 159-170.

[11] M. Daoudi, L. Serve, N. Rharbi, F. El Madani, F. Vouvé, Phytoplankton distribution in the Nador lagoon (Morocco) and possible risks for harmful algal blooms, Transit. Water. Bull 6 (2012) 4-19.

[12] S. Turki, N. Balti, First bloom of dinoflagellate Alexandrium catenella in Bizerte Lagoon (northern Tunisia), Harm. Algae News 35 (2008) 8-9.

[13] D.B. Smida, I. Sahraoui, H.H. Mabrouk, A.S. Hlaili, Dynamique saisonnière du genre Alexandrium (dinoflagellé potentiellement toxique) dans la lagune de Bizerte (Nord de la 

$406-416$.

275 [14] H. Frehi, A. Couté, G. Mascarell, C. Perrette-Gallet, M. Ayada, M.H. Kara, 276 Dinoflagellés toxiques et/ou responsables de blooms dans la baie d'Annaba (Algérie), C. 277 R. Biologies 330 (2007) 615-628.

278 [15] E. Garcés, M. Vila, M. Maso, N. Sampedro, M.G. Giacobbe, A. Penna, Taxon specific 279 analysis of growth and mortality rates of harmful dinoflagellates during bloom conditions. 280 Mar. Ecol. Prog. Ser. 301 (2005) 67-79.

281 [16] T. Takeuchi, Y. Yoshida, Relationship between the blooms of Alexandrium catenella and 282 the water quality or meteorological factors. Nippon Suisan Gakkaishi 65 (1999) 826-832.

[17] A. Luglié, M.G. Giacobbe, F. Fiocca, A. Sannio, N. Sechi, The geographical distribution 285 of Alexandrium catenella is extending to Italy ! First evidences from the Tyrrhenian Sea, in: K.A Steidinger, J.H. Landsberg, C.R. Tomas, G.A. Vargo, (Eds.), Harmful Algae 2002. Florida Fish and Wildlife Conservation Commission, Florida Institute of Oceanography, and Intergovernmental Oceanographic Commission of Unesco, St.Petersburg, Florida, USA, 2004, pp. 329-331.

[18] T.J. Smayda, C.S. Reynolds, Community assembly in marine phytoplankton: application of recent models to harmful dinoflagellate blooms. J Plankton Res 23 (2001) 447-461.

[19] D.M. Anderson, G.C. Pitcher, M. Estrada, The comparative "systems" approach to HAB 294 [20] Y. Collos, B. Béatrice, C. Jauzein, E. Abadie, T. Laugier, J. Lautier, A. Pastoureaud, P. 295 Souchu, A. Vaquer, Oligotrophication and emergence of picocyanobacteria and a toxic 296 dinoflagellate in Thau lagoon, southern France, J. Sea Research 61 (2009) 68-75. 
[21] F. Koroleff, Determination of nutrients: in Grasshoff, K. (Eds.), Methods of Seawater Analysis, Verlag Chemie, Weinheim, Germany, 1976, pp. 117-82.

[22] E.D. Wood, F.A.J. Armstrong, F.A. Richard, Determination of nitrate in sea water by cadmium copper-reduction to nitrite, J. Mar. Biol. Assoc. U.K. 47 (1967) 23-31.

[23] K. Bendschneider, R.J. Robinson, A new spectrophotometric method for the determination of nitrite in seawater. J. Mar. Res, 11 (1952) 87-96.

[24] J. Murphy, J.P. Riley, A modified single solution method for the determination of phosphate in natural waters. Anal. Chim. Acta, 27 (1962) 31-36

[25] C.J. Lorenzen, Determination of chlorophyll and pheo-pigments: spectrophotometric equations. Limnol. Oceanogr. 12 (1967) 343-346.

[26] O. Holm-Hansen, C.J. Lorenzen, R.W. Holmes, J.D.H. Strickland, Fluorometric determination of chlorophyll, J. Cons. int. Explor. Mer 30 (1965) 3-15.

[27] J. Neveux, F. Lantoine, Spectrofluorometric assay of chlorophylls and phaeopigments using the least squares approximation technique, Deep-Sea Res 40 (1993) 1747-1765.

[28] H. Utermöhl, Zur Vervollkommnung der quantitativen Phytoplankton-Methodik. Mitt. Int. Ver. Theor. Angew. Limnol. 9 (1958) 1-38.

[29] I. La Jeunesse, M. Elliott, Anthropogenic regulation of the phosphorus balance in the Thau catchment-coastal lagoon system (Mediterranean Sea, France) over 24 years. Mar. Poll. Bull. 48 (2004) 679-687.

[30] C. Jauzein, C. Labry, A. Youenou, J. Quéré, D. Delmas, Y. Collos, Growth and phosphorus uptake by the toxic dinoflagellate Alexandrium catenella (Dinophyceae) in response to phosphate limitation. J. Phycol. 46 (2010) 926-936.

[31] I. Imai, M. Yamaguchi, Y. Hori, Eutrophication and occurrences of harmful algal blooms in the Seto Inland Sea, Japan. Plankton Benthos Research 1 (2006) 71-84. 
[32] M. Yamaguchi, S. Itakura, K. Nagasaki, Y. Kotani, Distribution and abundance of resting cysts of the toxic Alexandrium spp. (Dinophyceae) in sediments of the western Seto Inland Sea, Japan, Fisheries Science 68 (2002) 1012-1019.

[33] A. Lugliè, M.G. Giacobbe, A. Sannio, F. Fiocca, N. Sechi, First record of the dinoflagellate Alexandrium catenella (Whedon \& Kofoid) Balech (Dinophyta), a potential producer of paralytic shellfish poisoning, in Italian waters (Sardinia, Tyrrhenian Sea). Bocconea 12 (2003) 1045-1051.

[34] M. Ounissi, H. Fréhi, Variabilité du microplancton et des Tintinnida (protozoaires ciliés) d'un secteur eutrophe du golfe d'Annaba (Méditerranée sud-occidentale), Cah. Biol. Mar. 40 (1999) 141-153.

No conflict of interest affecting the authors exists 
Table 1. General physical and chemical features at both sites. Range of values (monthly means) over several years (1992, 2002 and 2010 for Annaba; 1992 to 2010 for Thau). S :

salinity ; SRP : soluble reactive phosphorus ; SST : sea surface temperature ; U : undetectable

$\begin{array}{lllllll}\text { Site } & \text { SST } & \mathrm{S} & \mathrm{NO}_{3} & \mathrm{NH}_{4} & \mathrm{SRP} & \text { Chl a } \\ & \left({ }^{\circ} \mathrm{C}\right) & & (\mu \mathrm{M}) & (\mu \mathrm{M}) & (\mu \mathrm{M}) & (\mu \mathrm{g} / \mathrm{liter}) \\ \text { Annaba } & 14.1-28.6 & 35.3-38.1 & \mathrm{U}-65 & \mathrm{U}-110 & \mathrm{U}-43 & 0.8-32.8 \\ \text { Thau } & 5.0-25.6 & 29.5-39.2 & \mathrm{U}-20 & \mathrm{U}-10 & \mathrm{U}-10 & 0.3-37.4\end{array}$


Table 2. Changes in environmental factors at two coastal sites North and South of the Mediterranean for 3 selected years over an 18 year period.

Seasonal distributions are available at http://www.st.nmfs.noaa.gov/nauplius/media/time-series/site mediterranean-thau-lagoonphy/copepodite/index.html for Thau and in [34] and [14] for Annaba respectively in 1992 and 2002.

NA: not available; P: phosphorus; SD: standard deviation; SST: sea surface temperature.

\begin{tabular}{|c|c|c|c|c|c|c|c|c|c|c|c|c|c|c|c|}
\hline \multicolumn{2}{|l|}{ Year } & \multicolumn{2}{|l|}{ SST } & \multicolumn{3}{|c|}{ nitrate } & \multicolumn{3}{|c|}{ ammonium } & \multicolumn{3}{|c|}{ soluble reactive $\mathrm{P}$} & \multicolumn{3}{|c|}{ Chlorophyll a } \\
\hline Annab & & $\left({ }^{\circ} \mathrm{C}\right)$ & & $(\mu \mathrm{M})$ & & & $(\mu \mathrm{M})$ & & & $(\mu \mathrm{M})$ & & & $(\mu \mathrm{g} / \mathrm{li}$ & & \\
\hline & Mean & SD & $\mathrm{n}$ & mean & $\mathrm{SD}$ & $\mathrm{n}$ & mean & SD & $\mathrm{n}$ & mean & $\mathrm{SD}$ & $\mathrm{n}$ & mean & $\mathrm{SD}$ & $\mathrm{n}$ \\
\hline 1992 & 21.6 & 4.7 & 8 & 25.8 & 20.5 & 8 & 49.9 & 37.7 & 8 & 17.4 & 14 & 8 & 10.3 & 9.5 & 6 \\
\hline 2002 & 19.5 & 4.1 & 12 & 1.9 & 3.0 & 12 & 11.6 & 15.3 & 12 & 1.2 & 1.8 & 12 & 9.0 & 11.3 & 11 \\
\hline 2010 & 20.7 & 4.8 & 11 & 0.5 & 0.9 & 12 & 23.6 & 24.3 & 11 & 0.07 & 0.13 & 11 & 2.4 & 1.4 & 11 \\
\hline
\end{tabular}

Thau

$\begin{array}{llllllllllllllll}1992 & 18.4 & 7.1 & 12 & 0.5 & 0.5 & 11 & 1.4 & 3.1 & 10 & 1.2 & 1.2 & 10 & 1.5 & 0.6 & 9 \\ 2002 & 15.9 & 5.6 & 12 & 0.2 & 0.3 & 3 & 1.1 & 0.7 & 10 & 0.5 & 0.2 & 10 & 3.0 & 1.5 & 12 \\ 2010 & 15.1 & 6.9 & 12 & 0.2 & 0.1 & 3 & 0.7 & 0.6 & 3 & 0.2 & 0.1 & 3 & 2.2 & 1.1 & 11\end{array}$




\section{Figure legends}

348 1. Station positions in A nnaba Bay, A lgeria.

3492 2. Station positions in Thau lagoon, France.

$3503 . \quad$ Changes in monthly mean Alexandrium catenella/tamarense cell densities during 351 2002. Diamonds: Thau station A 5 ; squares : Thau station B ; triangles : A nnaba station 2. Detection limits: 100 cells $\mathrm{L}^{-1}$.

4. Changes in monthly mean Alexandrium catenella/tamarense cell densities during 2010.

354 Diamonds : Thau station A 5 ; Squares : Thau station B ; triangles : A nnaba station 2 ;

355 circles : A nnaba station 1. Detection limits: 100 cells L ${ }^{-1}$. 356 357 358 359 


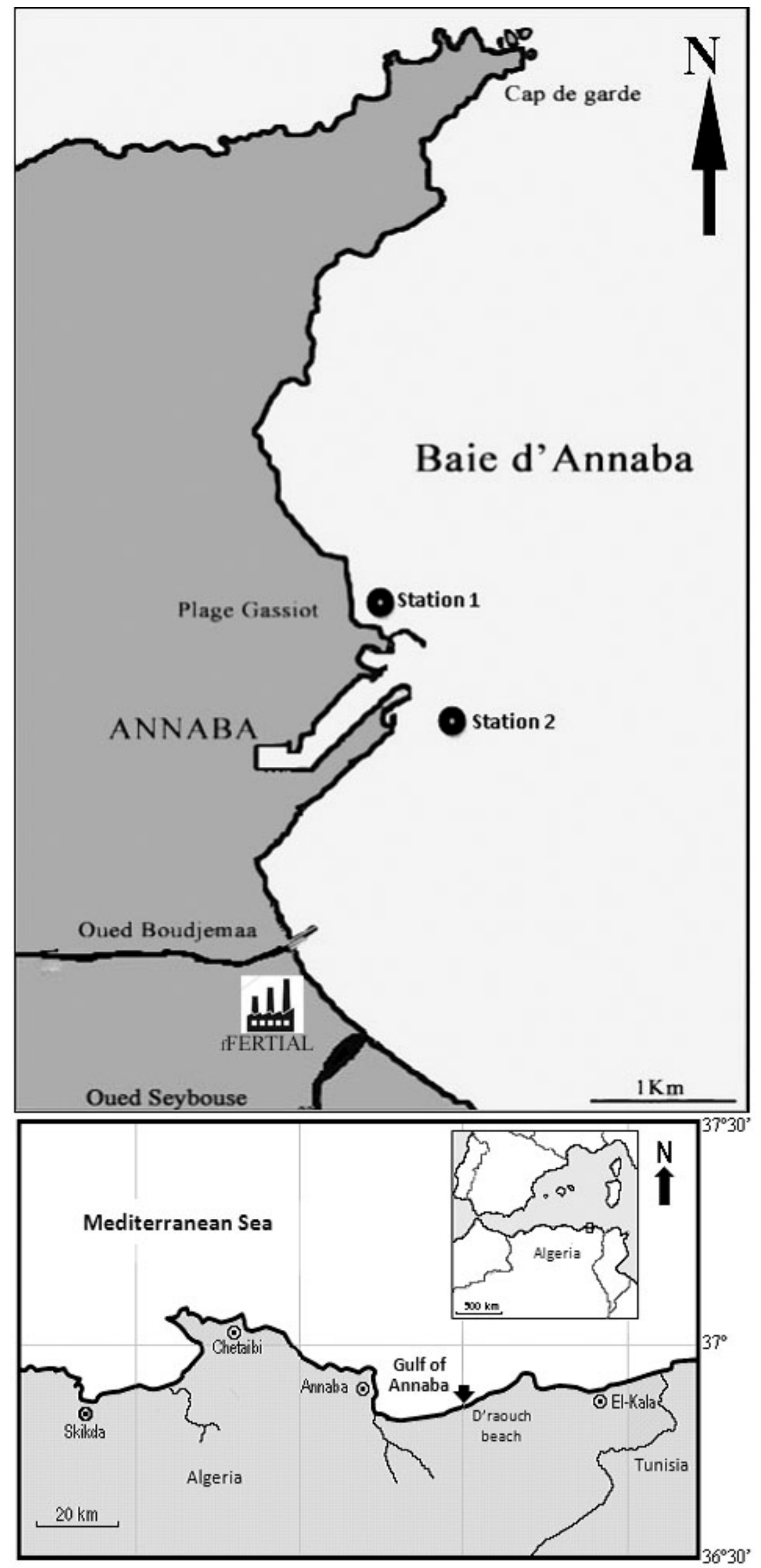




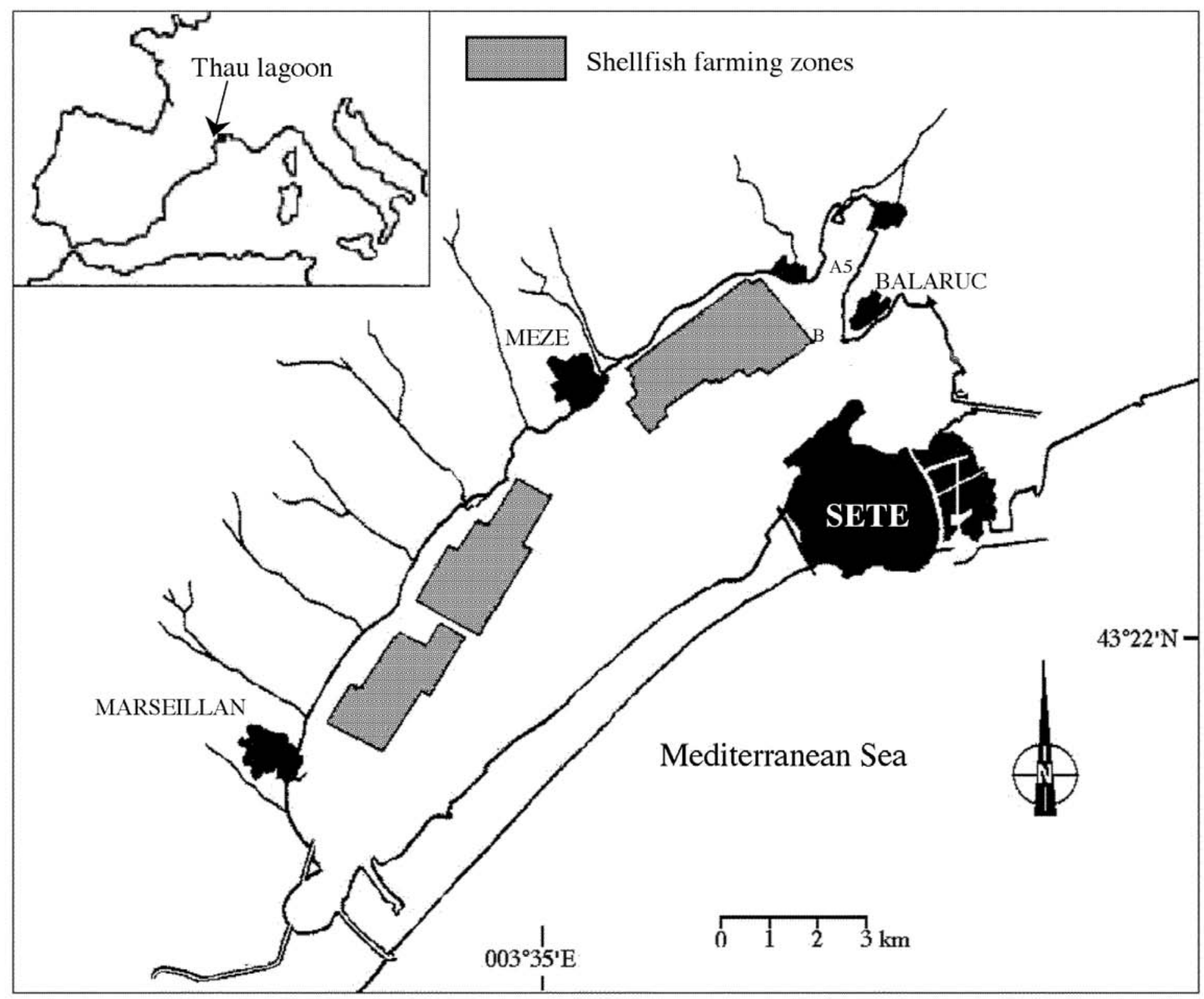




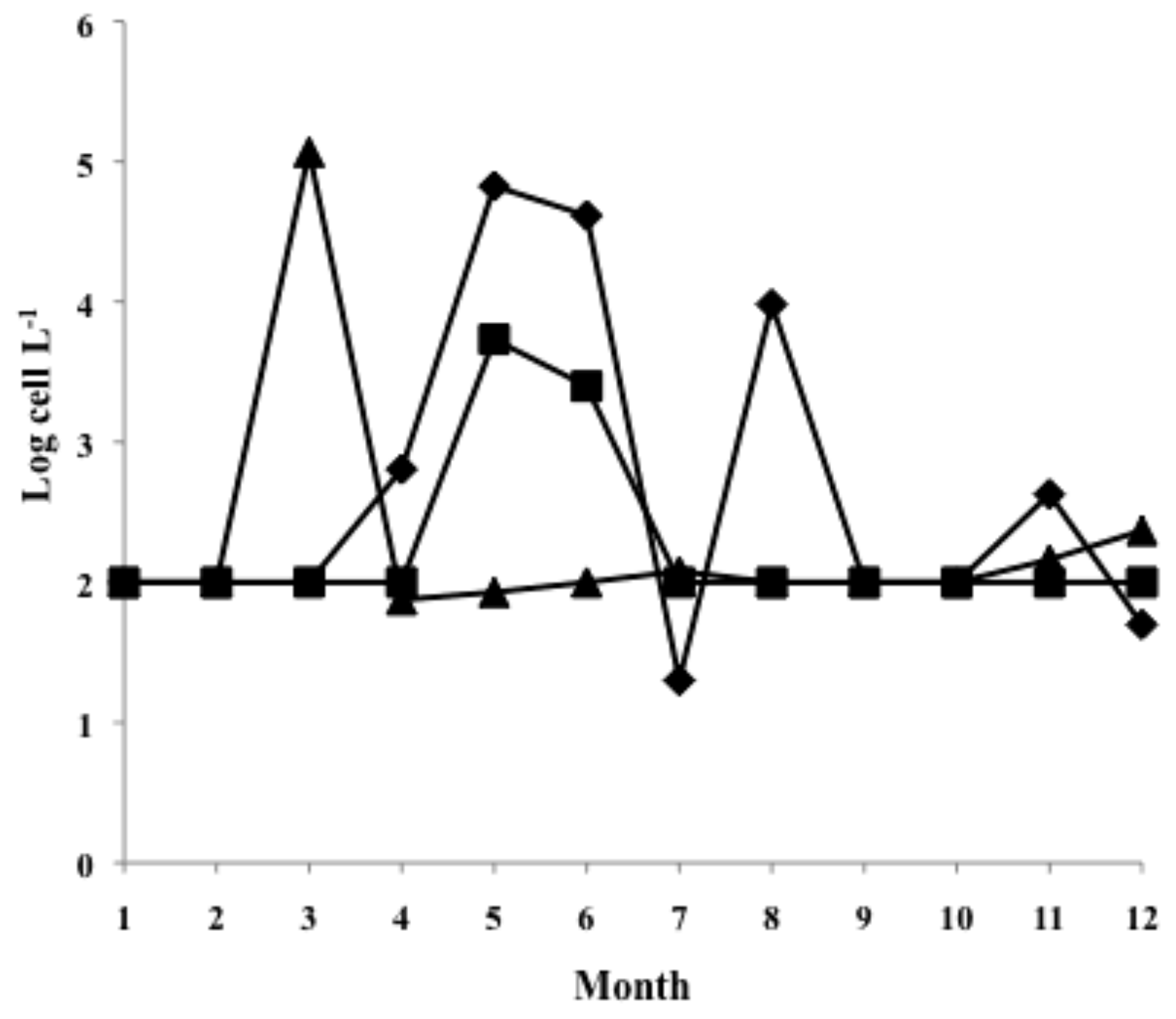




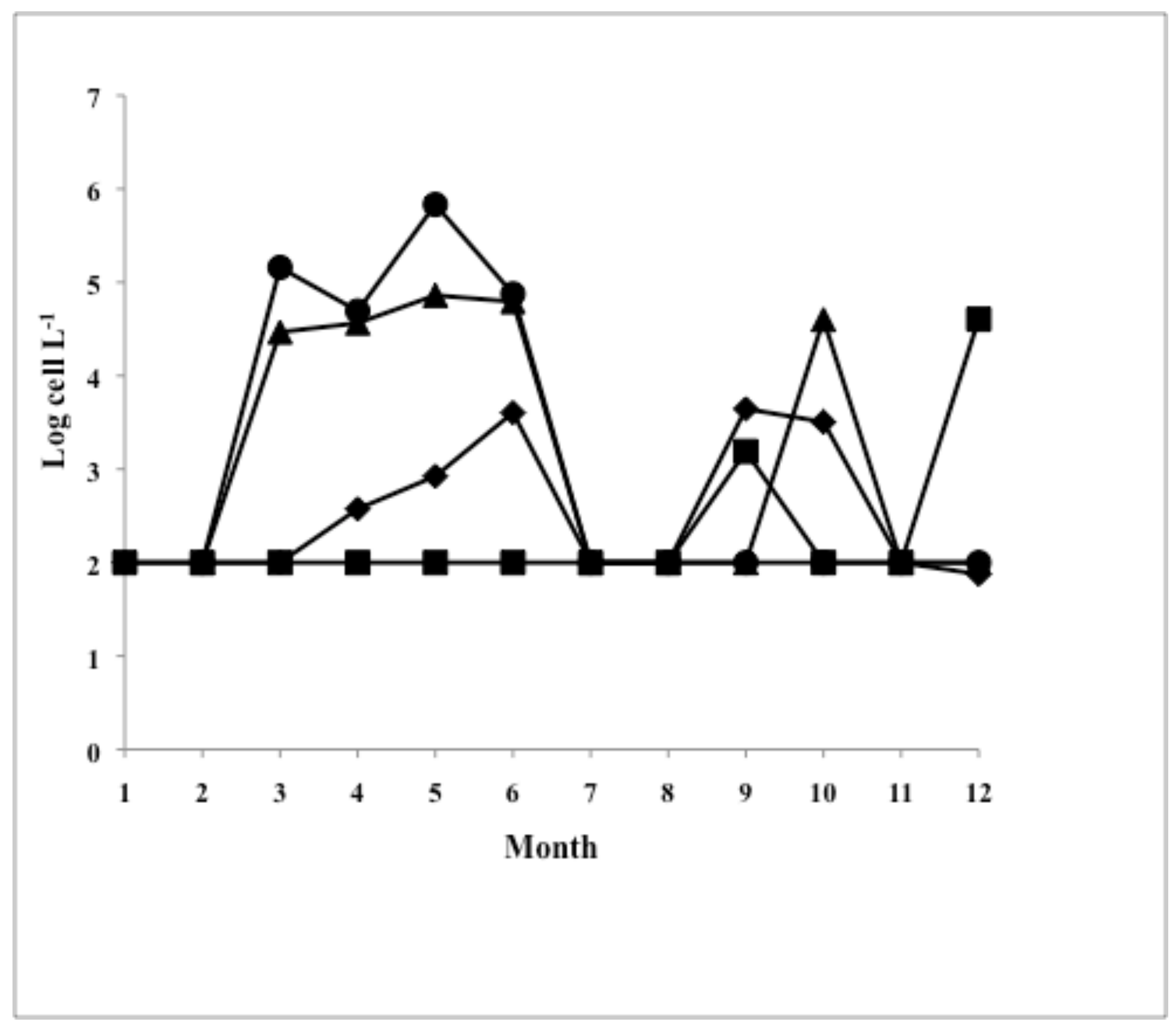

